\title{
Anthraquinones from the bark of Senna macranthera
}

\author{
ALEXSANDRO BRANCO ${ }^{1}$, ANGELO C. PINTO $^{2}$, JAN SCHRIPSEMA ${ }^{3}$ and RAIMUNDO BRAZ-FILHO ${ }^{4}$ \\ ${ }^{1}$ Laboratório de Fitoquímica, Departamento de Saúde, Universidade Estadual de Feira de Santana, \\ Av. Transnordestina, s/n, Bairro Novo Horizonte, 44036-900 Feira de Santana, BA, Brasil \\ ${ }^{2}$ Departamento de Química Orgânica, Instituto de Química, Universidade Federal do Rio de Janeiro, \\ Centro de Tecnologia, Bloco A, Cidade Universitária, Ilha do Fundão, 21945-970 Rio de Janeiro, RJ, Brasil \\ ${ }^{3}$ Grupo Metabolômica, Laboratório de Ciências Químicas, Universidade Estadual do Norte Fluminense Darcy Ribeiro, \\ Av. Alberto Lamego, 2000, Parque Califórnia, 28015-620 Campos dos Goytacazes, RJ, Brasil \\ ${ }^{4}$ Setor de Química de Produtos Naturais, LCQUI-CCT, Universidade Estadual do Norte Fluminense Darcy Ribeiro, \\ Av. Alberto Lamego, 2000, Parque Califórnia, 28015-620 Campos dos Goytacazes, RJ, Brasil
}

Manuscript received on March 23, 2010; accepted for publication on March 14, 2011

\begin{abstract}
2-acetyl physcion (2-acetyl-1,8-dihydroxy-6-methoxy-3-methyl-9,10-anthraquinone, 2), a rare anthraquinone, was isolated from Senna macranthera var. nervosa (Vogel) H.S. Irwin \& Barneby (Fabaceae). The chemical structure was elucidated and all ${ }^{1} \mathrm{H}$ and ${ }^{13} \mathrm{C}$ NMR chemical shifts were assigned by NMR one- $\left({ }^{1} \mathrm{HNMR},\left\{{ }^{1} \mathrm{H}\right\}-{ }^{13} \mathrm{CNMR}\right.$, and APT- $\left.{ }^{13} \mathrm{CNMR}\right)$ and two (COSY, NOESY, HMQC and HMBC) dimensional of this natural compound. Furthermore, the minor anthraquinones chrysophanol (3), chrysophanol-8-methyl ether (4) and physcion (5) were characterized by GC-MS analysis. The occurrence of the anthraquinones 3-5 confirms that $S$. macranthera is a typical representative of the genus Senna.
\end{abstract}

Key words: anthraquinone, 2-acetyl-physcion, Fabaceae, Senna macranthera.

\section{INTRODUCTION}

The genus Senna is known to produce various classes of aromatic compounds, e.g. quinones, normal (Barba et al. 1992) and dimeric anthraquinones (Koyama et al. 2001), naphthopyrones (Barbosa et al. 2004) and flavonoids (Baez et al. 1999). S. macranthera var. nervosa (Vogel) H.S. Irwin \& Barneby (syn. Cassia macranthera), commonly known as "alleluia" (subfamily Papilionoidae, family Fabaceae), is a 6-8 $\mathrm{m}$ high tree with a trunk of up to $30 \mathrm{~cm}$ of diameter. The leaves are composed of two pairs of opposing leaflets. In Brazil, the tree is found from Ceará in the North down to São Paulo in the South. It is used mainly as an ornamental plant in cities because of lush yellow flowers and rapid growth (Lorenzi 2000). Previous phytochemical

Correspondence to: Alexsandro Branco

E-mail: branco@uefs.br studies on the bark of $S$. macranthera collected in Belo Horizonte, Brazil, revealed the presence of rubrofusarin (1), 6-O-galactosylrubrofusarin, 3,5-dihydroxy-8-isobutenyl-2-methyl-7-methoxychromone and $\beta$-sitosterol (Oliveira et al. 1977). A galactomannan with anticoagulant activity has been isolated from the endosperm of seeds (Pires et al. 2001).

The anthraquinones are traditionally used as pigments and medicines, and are widely distributed in nature, occurring in both free and glycosidic form (Bruneton 1991). Several analytical methods have been used to analyse these compounds, including gas chromatography coupled to mass spectrometry (GC-MS) (Waterman and Mole 1994). This method permits the analysis of non-glycosylated anthraquinones with (Zuo et al. 2008) or without derivatisation (Mueller et al. 1999, Liu et al. 2007). 
In this paper we report the identification of 2-acetyl physcion (2) by spectrometric methods, together with the characterisation of others minor anthraquinones (35) (Fig. 1) using GC-MS analysis from S. macranthera.

\section{MATERIALS AND METHODS}

\section{General ExPerimental Procedures}

NMR spectra were recorded in $\mathrm{CDCl}_{3}$ solution at 400 $\mathrm{MHz}$ for ${ }^{1} \mathrm{H}$ and $100 \mathrm{MHz}$ for ${ }^{13} \mathrm{C}$ on a JEOL Eclipse+ 400 spectrometer. Chemical shift values are reported relative to TMS, which was either used as internal standard or by reference to solvent signals: $\mathrm{CHCl}_{3}$ at $\delta_{H}$ 7.26 and at $\delta_{C}$ 77.00. GC analyses were recorded on a Hewlett Packard model 5790 A gas chromatograph using glass capillary column $(11 \mathrm{~m} \times 0.25 \mu \mathrm{m})$ coated with SE-54 $(\mathrm{df}=0.25 \mu \mathrm{m})$. GC-MS spectra were run at $70 \mathrm{eV}$ on a Shimadzu QP-2000 spectrometer. The data were collected on an HP 3396-II integrator. TLC: silica gel (Merck, Kieselgel 60), spots visualised by UV (254 and $360 \mathrm{~nm}$ ) and exposure to $\mathrm{I}_{2}$ vapour. TLC was used to analyse fractions collected from $\mathrm{CC}$.

\section{Plant Material}

The bark of $S$. macranthera was collected in Campinas, São Paulo State, Brazil, in September 2000. The identification was performed by Marcia Dias Campos, and a voucher specimen (n. 89281) is deposited at the Herbarium of the State University of Feira de Santana, Brazil.

\section{EXTRACTION AND ISOLATION}

The bark (500 g) of $S$. macranthera was dried at controlled temperature $\left(60^{\circ} \mathrm{C}\right)$. After drying, the bark was shred and extracted with $n$-hexane $(2 \mathrm{~L})$ and dichloromethane (2 L) at room temperature for seven days each, successively. During the evaporation of the hexane under reduced pressure in the rotary evaporator, the formation of a red coloured precipitate was observed, filtered and identified as rubrofusarin 1 (2.0 g) (Branco et al. 2008). The residue, after further drying, yielded the respective hexane extract $(9.1 \mathrm{~g})$ that was chromatographed with a gradient of EtOAc in hexane to furnish an additional quantity of $\mathbf{1}(0.8 \mathrm{~g})$. The dichloromethane extract (52.0 g) was also chromatographed on a silica gel column $(65.3 \mathrm{~g})$ in the same manner to yield a total of 10 fractions of $c a .100 \mathrm{~mL}$ each that were collected and combined on the basis of TLC comparison. Fraction 3 eluted with hexane/EtOAc (3:1), furnished 2 as red crystals $(6.5 \mathrm{mg})$. The fractions 8-9 eluted with EtOAc/EtOH (1:1), were united and analysed by GC-MS (Fig. 2).

\section{2-ACETYL PHYSCION 2}

Red solid; IR (KBr) $v_{\max } \mathrm{cm}^{-1}: 3442,1700,1691,1615$, 1598, 1474, 1443, 1208, 1235, 1165; ${ }^{1} \mathrm{H}[400 \mathrm{MHz}$, $\left.\mathrm{CDCl}_{3}\right]: \quad \delta_{\mathrm{H}} 7.65$ (s, H-4), 7.38 (d, $J=2.6 \mathrm{~Hz}, \mathrm{H}-$ 5), $6.71(\mathrm{~d}, J=2.6 \mathrm{~Hz}, \mathrm{H}-7), 3.95$ (s, MeO-6), 2.61 (s, 3H-12), 2.39 (s, 3H-13), 12.48 (s, $\underline{\mathrm{HO}}-1), 12.18$ (s, HO-8). ${ }^{13} \mathrm{C}$ NMR [75 MHz, $\mathrm{CDCl}_{3}$ ]: $\delta_{\mathrm{C}} 159.28(\mathrm{C}-1)$, 136.30 (C-2), 144.59 (C-3), 135.03 (C-4a), 166.88 (C6), 165.42 (C-8), 110.15 (C-8a), 190.65 (C-9), 114.09 (C-9a), 181.46 (C-10), 133.01 (C-10a), 203.03 (C-11), 122.08 (C-4), 108.75 (C-5), 106.86 (C-7), 56.17 (MeO6), 31.85 (C-12), 20.13 (C-13). GC-MS (70 eV) $\mathrm{m} / z$ (rel. int.): $326\left([\mathrm{M}]^{\bullet+}, 68 \%\right), 311\left(\mathrm{M}-\mathrm{Me}^{\bullet}, 100\right), 308$ $\left(\mathrm{M}-\mathrm{H}_{2} \mathrm{O}, 15\right), 298$ (M-CO, 1), 283 ( $\mathrm{m} / \mathrm{z}$ 311-CO, 3), 255 ( $m / z$ 283-CO, 2), $227(m / z$ 255-CO, 9).

\section{GC-MS ANALYSIS}

Hydrogen as carrier gas; flow rate of $2 \mathrm{~mL} / \mathrm{min}$; injector port was set at $280^{\circ} \mathrm{C}$ and flame ionization detector (FID) at $290^{\circ} \mathrm{C}$. The temperature program for the analysis of mixtures ranged from $260^{\circ} \mathrm{C}$ to $280^{\circ} \mathrm{C}$. The GCMS interface was at $350^{\circ} \mathrm{C}$, and ion source temperature at $300^{\circ} \mathrm{C}$.

\section{RESULTS AND DISCUSSION}

The IR spectrum of compound 2 showed bands for two hydroxyl groups $\left(v_{\max } 3442 \mathrm{~cm}^{-1}\right)$, three carbonyl groups $\left(v_{\max } 1700,1615\right.$ and $1598 \mathrm{~cm}^{-1}$ ) and aromatic rings $\left(v_{\max } 1550\right.$ and $\left.1474 \mathrm{~cm}^{-1}\right)$. The ${ }^{1} \mathrm{H}$ NMR spectrum revealed signals corresponding to the presence of two peri-positioned chelated hydroxyl groups $\left(\delta_{\mathrm{H}}\right.$ 12.48, HO-1, and 12.18, HO-8) (Schripsema and Dagnino 1996), three aromatic hydrogens [one singlet at $\delta_{\mathrm{H}}$ $7.65(\mathrm{H}-4)$ and two doublets compatible with two metacoupled hydrogen atoms at $\delta_{\mathrm{H}} 7.38(\mathrm{~d}, J=2.6 \mathrm{~Hz})$ and $6.71(\mathrm{~d}, J=2.6 \mathrm{~Hz})]$, one methoxyl function $\left(\delta_{\mathrm{H}}\right.$ $3.95)$ and two methyl groups linked to $\mathrm{sp}^{2}$ carbon atoms $\left[\delta_{\mathrm{H}} 2.61(\mathrm{~s}, 3 \mathrm{H}-12)\right.$ and $\left.2.39(\mathrm{~s}, 3 \mathrm{H}-13)\right]$. These data and comparative analysis of $\left\{{ }^{1} \mathrm{H}\right\}-$ and APT- $-{ }^{13} \mathrm{C}$ NMR 
<smiles>COc1cc(O)c2c(O)c3c(=O)cc(C)oc3cc2c1</smiles>

1<smiles>[R]Oc1cccc2c1C(=O)c1c(O)cc(C)cc1C2=O</smiles>

$\mathbf{R}$

$3 \mathrm{H}$

$4 \quad \mathrm{CH}_{3}$<smiles>COc1cc(O)c2c(c1)C(=O)c1cc(C)c(C(C)=O)c(O)c1C2=O</smiles>

2<smiles>COc1cc(O)c2c(c1)C(=O)c1cc(C)cc(O)c1C2=O</smiles>

Fig. 1 - Structures of identified compounds in S. macranthera.

spectra [twelve $\mathrm{sp}^{2}$ quaternary carbon atoms, including three carbonyl groups at $\delta_{\mathrm{C}} 203.03$ (C-11), 190.65 (C-9) and $181.46(\mathrm{C}-10)]$, three $\mathrm{sp}^{2}$ methines and three methyl groups at $\left[\delta_{\mathrm{C}} 56.17\left(\mathrm{CH}_{3} \mathrm{O}\right), 31.85\left(\mathrm{CH}_{3}-12\right.\right.$, acetyl function) and $\left.20.13\left(\mathrm{CH}_{3}-13\right)\right]$, together with the molecular ion in the mass spectrum at $m / z 326\left([\mathrm{M}]^{+}\right.$, $58 \%$ ), suggested the structure of this physcion derivative.

Heteronuclear 2D shift-correlated NMR techniques ${ }^{1} \mathrm{H}_{-}{ }^{13} \mathrm{C}-\mathrm{COSY}-{ }^{1} \mathrm{~J}_{\mathrm{CH}}$ (HMQC) and ${ }^{1} \mathrm{H}_{-}{ }^{13} \mathrm{C}-\mathrm{COSY}-$ ${ }^{n} J_{C H}$ (HMBC) were used for the correct ${ }^{1} \mathrm{H}$ and ${ }^{13} \mathrm{C}$ NMR chemical shift assignments of anthraquinone 2 . The location of the acetyl group at carbon atom C-2 was confirmed by heteronuclear long-range couplings C-2 $\left(\delta_{\mathrm{C}}\right.$ $136.30)$ and HO-1 $\left(\delta_{\mathrm{H}} 12.48,{ }^{3} \mathrm{~J}_{\mathrm{CH}}\right), \mathrm{H}-4\left(\delta_{\mathrm{H}} 7.65,{ }^{3} \mathrm{~J}_{\mathrm{CH}}\right)$ and both $3 \mathrm{H}-12\left(\delta_{\mathrm{H}} 2.61,{ }^{3} \mathrm{~J}_{\mathrm{CH}}\right)$ and $3 \mathrm{H}-13\left(\delta_{\mathrm{H}} 2.39\right.$, $\left.{ }^{3} \mathrm{~J}_{\mathrm{CH}}\right)$. The ${ }^{1} \mathrm{H}-{ }^{1} \mathrm{H}-\mathrm{NOESY}$ spectrum further confirmed the structure, showing interactions between $3 \mathrm{H}-13$ and $\mathrm{H}-4$, and between the methoxyl group and both $\mathrm{H}-5$ and $\mathrm{H}-7$.

Thus, the structure of 2 was established as 1,8 dihydroxy-2-acetyl-3-methyl-6-methoxy- 9, 10-anthraquinone (2-acetyl physcion). This is the first report of the antraquinone 2 in a Senna species. All ${ }^{1} \mathrm{H}$ and ${ }^{13} \mathrm{C}$ chemical shifts were unambiguously assigned. This compound has been reported only once in the literature (Wei et al. 2007), and the attributions to the carbons $\mathrm{C}-4 \mathrm{a}\left(\delta_{\mathrm{C}} 135.03\right)$ and $\mathrm{C}-10 \mathrm{a}\left(\delta_{\mathrm{C}} 133.01\right)$ were corrected.

The fractions of the dichloromethane extract obtained by $\mathrm{SiO}_{2}$ fractionation were analysed by GC-MS to detect other polyketid. Only the fraction 8-9 showed the presence of peaks the typical fragmentation pattern of anthraquinones: intense molecular ion, loss of $\mathrm{CO}$ $(28 \mathrm{Da})$ and other fragmentations with weak intensity (Song et al. 2009). Figure 2 and Table I show the chromatogram and mass spectra of this fraction, respectively. The peaks corresponding to $\operatorname{Tr}$ at 14.6,16.1 and $17.3 \mathrm{~min}$ showed molecular ion base peaks $\left([\mathrm{M}]^{\bullet+}, 100 \%\right)$ at $m / z$ 254, 268 and 284, and loss of CO to furnish peaks at $m / z 226$ (13\%), 240 (4\%) and $256(5 \%)$, respectively. The molecular mass of $4\left([\mathrm{M}]^{\bullet+}, m / z 268\right)$ is $14 \mathrm{Da}$ higher than $3\left([\mathrm{M}]^{\bullet+}, m / z 254\right)$, indicating the presence of an additional methylene unit. This $-\mathrm{CH}_{2}$ - unit was attributed to formation of one methoxyl group at $\mathrm{C}-8$ (C-OH to $\left.\mathrm{C}-\mathrm{OCH}_{3}\right)$.

Thus, the GC-MS analyses permitted the identification of chrysophanol (3), chrysophanol-8-methyl ether 
TABLE I

CG-MS data of anthraquinones 3-5.

\begin{tabular}{c|c|c|c|c|c|c|c|c}
\hline \multirow{2}{*}{ Structure } & \multirow{2}{*}{$\mathrm{Rt}^{\mathrm{a}}$} & \multirow{2}{*}[\mathrm{M}]{$^{\bullet+}$} & \multicolumn{6}{c}{ F r g m e n t } \\
\cline { 4 - 9 } & & & $\bullet \mathrm{CH}_{3}$ & $\bullet \mathrm{OH}$ & $\mathrm{CO}$ & $\mathrm{H}_{2} \mathrm{CO}$ & $\mathrm{CO}+\bullet \mathrm{CH}_{3}$ & Other fragments \\
\hline $\mathbf{3}$ & 14.6 & $254(100 \%)$ & $239(1)$ & - & $226(13)$ & - & - & $197(8), 152(7), 127(4), 115(3)$ \\
\hline $\mathbf{4}$ & 16.1 & $268(100)$ & $253(9)$ & $251(8)$ & $240(4)$ & $238(5)$ & $225(12)$ & $211(1), 197(3), 165(9)$ \\
\hline $\mathbf{5}$ & 17.3 & $284(100)$ & - & - & $256(5)$ & $254(6)$ & $241(9)$ & $226(5), 213(6), 185(3), 139(4)$ \\
\hline \multicolumn{4}{c}{ " Retention time in minute. }
\end{tabular}

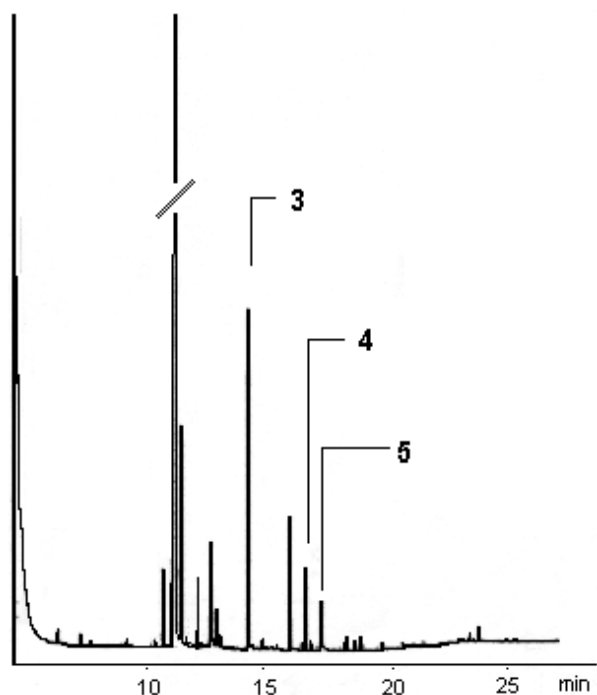

Fig. 2 - GC chromatogram of the fraction 8-9 isolated from $S$. macranthera containing anthraquinones 3-5.

(4) and physcion (5) in S. macranthera. The occurrence of 3-5 is rather common in species of the genus Senna (Barba et al. 1992). The other hand, the occurrence these compounds in the same plant is common in the nature (Mueller et al. 1999), which can be explain by the biosynthetic route (Dewick 1997). Chrysophanol, chrysophanol-8-methyl ether and physcion present in extracts from plants were thought to be responsible for antimicrobial (Hatano et al. 1999, García-Sosa et al. 2006) and other biological activities (Tewtrakul et al. 2007).

\section{ACKNOWLEDGMENTS}

We would like to thank Fundação Carlos Chagas Filho de Amparo à Pesquisa do Estado do Rio de Janeiro (FAPERJ, Brazil), Conselho Nacional de Desenvolvimento Científico e Tecnológico (CNPq, Brazil), Fundação Universitária José Bonifácio (FUJB, UFRJ, Rio de Janeiro, Brazil) and Programa de Apoio a Núcleos de Excelência (PRONEX) (Grant 4002, Brazil) for financial support.

\section{RESUMO}

2-acetil-fisciona (2-acetil-1,8-di-hidróxi-6-metóxi-3-metil-9, 10-antraquinona, 2), uma antraquinona rara, foi isolada de Senna macranthera var. nervosa (Vogel) H.S. Irwin \& Barneby (Fabaceae). A estrutura química foi elucidada e todos os deslocamentos químicos de $\mathrm{RMN}{ }^{1} \mathrm{H}$ e ${ }^{13} \mathrm{C}$ foram atribuídos através de RMN uni- $\left(\mathrm{RMN}^{1} \mathrm{H},\left\{{ }^{1} \mathrm{H}\right\}-\mathrm{RMN}-{ }^{13} \mathrm{C}\right.$ e APT$\mathrm{RMN}^{13} \mathrm{C}$ ) e bi- (COSY, NOESY, HMQC e HMBC) dimensional deste composto natural. Adicionalmente, as antraquinonas minoritárias crisofanol (3), crisofanol-8-metil éter (4) e fisciona (5) foram caraterizadas pela análise de CG-EM. A ocorrência das antraquinonas 3-5 confirma que $S$. macranthera é uma típica representante do gênero Senna.

Palavras-chave: antraquinona, 2-acetil-fisciona, Fabaceae, Senna macranthera.

\section{REFERENCES}

Barba B, Díaz JG And Herz W. 1992. Anthraquinones and others constituents of two Senna species. Phytochemistry 31: 4374-4375.

Baez DA, Vallejo LGZ and Jimenez-Estrada M. 1999. Phytochemical studies on Senna skinneri and Senna wislizeni. Nat Prod Res 13: 223-228.

BARbosa FG, OLIVEIRA MCF, BRAZ-FILHO R AND SILVEIRA ER. 2004. Anthraquinones and naphthopyrones from Senna rugosa. Biochem Syst Ecol 32: 363-365.

Branco A, Pinto AC, Braz-Filho R, Silva EF, GrynBERG NF AND ECHEVARRIA A. 2008. Rubrofusarina, um policetídeo natural inibidor da topoisomerase II- $\alpha$ humana. Rev Bras Farmacogn 18(suppl): 703-708.

BRUNETON J. 1991. Elementos de fitoquímica y de farmacognosia. Zaragoza: Acribia, 1128 p.

DEWICK PM. 1997. Medicinal Natural Products - A biosynthetic Approach. J Wiley \& Sons. England, 466 p.

García-Sosa K, Villareal-Alvarez N, Lubben P 
AND PeÑA-Rodriguez LM. 2006. Chrysophanol, an antimicrobial anthraquinone from the root extract of Colubrina greggii. J Mex Chem Soc 50: 76-78.

Hatano T, Uebayashi H, Ito H, Shiota S, Tsuchiya T AND YoshidA T. 1999. Phenolic constituents of Cassia seeds and antibacterial effect of some naphthalenes and anthraquinones on methicillin-resistent Staphylococcus aureus. Chem Pharm Bull 47: 1121-1127.

Koyama J, Morita I, TAgahara K AND AqIL M. 2001. Biantraquinones from Cassia siamea. Phytochemistry 56: 849-851.

LiU S-Y, LO C-T, CHEN C, LIU M-Y, CHEN J-H AND PENG K-C. 2007. Efficient isolation of anthraquinonederivatives from Trichoderma harzianum ETS 323. J Biochem Biophys Methods 70: 391-395.

LORENZI H. 2000. Árvores Brasileiras - Manual de identificação e cultivo de plantas arbóreas nativas do Brasil. São Paulo: Instituto Plantarum, 352 p.

Mueller So, Schmitt M, Dekant W, Stopper H, Schlatter J, Schreier P AND Lutz WK. 1999. Occurrence of emoldin, chrysophanol and physion in vegetables, herbs and liquors. Genotoxicity and anti-genotoxicity of the anthraquinones and of the whole plants. Food Chem Toxicol 37: 481-491.

Oliveira AB, Fernandes MLM, ShaAt VT, VASCONCElos LA AND GotTlieb OR. 1977. Constituents of Cassia species. Rev Latinoamer Quim 8: 82-85.
Pires L, Gorin PAJ, REICHER F AND SIERAKOWSKI MR. 2001. An active heparinoid obtained by suphation of a galactomannan extracted from the endosperm of Senna macranthera seeds. Carboh Pol 46: 165-169.

SCHRIPSEMA J AND DAGNINO D. 1996. Elucidation of the substitution pattern of 9,10-anthraquinones through the chemical shifts of peri-hydroxyl protons. Phytochemistry 42: 177-184.

Song R, Lin H, Zhang Z, Li Z, XU L, DONG H AND TIAN Y. 2009. Profiling the metabolic differences of anthraquinone derivatives using liquid chromatography/ tandem mass spectrometry with data-dependent acquisition. Rapid Commun Mass Spectrom 23: 537-547.

TEWTRAKul S, Subhadhirasakul S, RattanasuWAN P AND Puripattanvong J. 2007. HIV-1 protease inhibitory substances from Cassia garrettiana. Songklanakarin J Sci Technol 29: 145-149.

WAterman PG AND Mole S. 1994. Analysis of phenolic plants metabolites. London: Blackwell Scientific publications, $238 \mathrm{p}$.

Wei X, JiAng JS, Feng ZM ANd ZANG PC. 2007. New anthraquinone derivatives from roots of Berchemia floribunda. Chin Chem Let 18: 412-414.

Zuo Y, WANG C, Lin Y, Guo J And Deng Y. 2008. Simultaneous determination of anthraquinones in radix Polygony multiflori by gas chromatography coupled with flame ionization and mass spectrometric detection. J Chromatogr A 1200: 43-48. 